Proceeding Paper

\title{
Nano-Phytoremediation of Heavy Metals Contaminated Wastewater Ecosystems and Wetlands by Constructed Wetlands Planted with Waterlogging-Tolerant Mycorrhizal Fungi and Vetiver Grass ${ }^{+}$
}

\author{
Abdul G. Khan \\ Department of Academic, Western Sydney University, Ambarvale, NSW 2560, Australia; \\ lasara1937@gmail.com \\ † Presented at the 2nd International Electronic Conference on Mineral Science, 1-15 March 2021; \\ Available online: https://iecms2021.sciforum.net/.
}

Citation: Khan, A.G. NanoPhytoremediation of Heavy Metals Contaminated Wastewater Ecosystems and Wetlands by Constructed Wetlands Planted with Waterlogging-Tolerant Mycorrhizal Fungi and Vetiver Grass. Environ. Sci. Proc. 2021, 6, 25. https://doi. org/10.3390/iecms2021-09385

Academic Editor: Paul Sylvester

Published: 5 March 202

Publisher's Note: MDPI stays neutral with regard to jurisdictional claims in published maps and institutional affiliations.

Copyright: $@ 2021$ by the authors. Licensee MDPI, Basel, Switzerland. This article is an open access article distributed under the terms and conditions of the Creative Commons Attribution (CC BY) license (http://creativecommons.org/licenses/by/4.0/)

\begin{abstract}
Wetlands and aquatic ecosystems, which are an important part of the ecological system and national resources that need to be well managed, are becoming polluted by toxic heavy metals (HMs) from the industrial mining and smelting of metalliferous ores, and agricultural activities. The loss of wetlands may cause a loss of flora and fauna and thereby decrease biodiversity. Waterlogging resistant plants, their root associated microbes (Arbuscular Mycorrhizal Fungi (AMF)) and plant growth promoting rhizobia (PGPR) can provide potential tools in constructed wetlands (CWs) in order to allow for the Nano-Mycorrhizo-Phytoremediation (NMPR) of HM-polluted natural wetlands and aquatic ecosystems. AMF-CW systems should be considered ideal locations for the technical installations for phytoremediation and need to be optimized for the efficient functioning of phytoremediation in field trials. This presentation will address one of the major hurdles in the production of large quantities of indigenous and stress-adapted AMF inoculum for the purposes of constructing artificial AM-CW systems. The significance and potential role of floating islands of aquatic macrophytes such as Vetiver grass and their root associated microbes (AMF and PGPR) in an environmental cleanup of HM contaminated industrial, municipal, and mining effluents, will be highlighted in the presentation. During the environmental and pollutant stresses, the aquatic macrophytes and their root associated microbes produce nano-molecules of HM-binding cysteine-rich peptides, phytochelators (nano-molecules) forming HM-complexes that sequester HM-ions, protecting the host from contaminants. HM-adapted AMF not only enhance Vetiver grass growth, producing a greater biomass for bio energy production, but also uptake/stabilize HMs, e.g., Nano-Mycorrhizo-Phytoremediation (NMPR).
\end{abstract}

Keywords: Nano Phytoremediation; Plant-Growth Promoting Rhizobia; Arbuscular Mycorrhizal Fungi (AMF); Constructed Wetlands; Phytochelatins; AMF-inoculum; Aquatic Macrophytes; Vetiver Grass; Metal-Binding Cysteine-rich Nanomolecules

Supplementary Materials: The following are available online at https://www.mdpi.com/26734931/6/1/25/s1.

Institutional Review Board Statement: Not applicable.

Informed Consent Statement: Not applicable.

Data Availability Statement: Not applicable. 